\title{
Personal and environmental factors associated with active commuting to school in Switzerland
}

\author{
Bettina Bringolf-Isler ${ }^{\mathrm{a}, *}$, Leticia Grize ${ }^{\mathrm{a}}$, Urs Mäder ${ }^{\mathrm{b}}$, Nicole Ruch ${ }^{\mathrm{b}}$, \\ Felix H. Sennhauser ${ }^{\mathrm{c}}$, Charlotte Braun-Fahrländer ${ }^{\mathrm{a}}$ \\ SCARPOL team ${ }^{1}$ \\ ${ }^{a}$ Department of Environmental Health, Institute of Social and Preventive Medicine, University of Basel, Steinengraben 49, CH-4051 Basel, Switzerland \\ ${ }^{\mathrm{b}}$ Federal Institute of Sport, Magglingen, Switzerland \\ ' Pediatric Pneumology, University Children's Hospital, Zurich, Switzerland
}

Available online 4 July 2007

\begin{abstract}
Objective. To assess whether prevalence of active commuting and regular car trips to school varies across communities and language regions in Switzerland and to determine personal and environmental correlates.

Methods. During the school year 2004/2005, 1345 parental questionnaires (response rate 65\%) of children attending 1st, 4th and 8th grades were completed, 1031 could be linked to a GIS environmental database. A German-speaking, a French-speaking and a bilingual study area were included. Usual mode of transportation and frequency of regular car trips to school were assessed. Associations with personal and environmental factors were evaluated with multivariate regression models.

Results. Seventy-eight percent of the children actively traveled to school. Twelve percent were regularly driven at least once a week by car. Major road crossings and distance were significantly related to usual mode of transportation, but not to regular car trips. Age, daycare attendance, parental safety concerns, number of cars in the household and belonging to French-speaking population were significantly associated with increased regular car trips.

Conclusion. Objective predictors are main deciding factors for active commuting to school as main mode of transport whereas personal and lifestyle factors are important factors associated with frequency of car use. Not only objective but also differing cultural attitudes should be considered when promoting non-motorized travel.
\end{abstract}

(C) 2007 Elsevier Inc. All rights reserved.

Keywords: Active mode of transportation; Children; Cultural factors; Environment

\section{Introduction}

Active commuting to school is an opportunity for children to achieve regular daily physical activity and may thus decrease the risk of several health conditions later in life (Biddle et al., 2004; Andersen et al., 2006). In children and adolescents, walking and cycling to school has been associated with increased daily energy expenditure and increased

* Corresponding author. Fax: +416127022 25.

E-mail address: Bettina.Bringolf@unibas.ch (B. Bringolf-Isler).

${ }^{1}$ C. Bezençon, C. Braun-Fahrländer, B. Bringolf-Isler, M.I. Carvajal, P.A. Eigenmann, M. Gassner, L. Grize, U. Heininger, U. Neu, P. SchmidGrendelmeier, F.H: Sennhauser, D. Stamm, P. Staehl, T. Stricker, K. TakkenSahli, B. Wüthrich. cardiovascular fitness compared with those traveling by car (Sirard et al., 2005; Mackett et al., 2005; Tudor-Locke et al., 2002; Cooper et al., 2006). The proportion of children walking and cycling to school varies considerably across countries (Roberts et al., 1997, Hillman et al., 1990): in the United States, approximately $50 \%$ of children travel to school by car, with only $10 \%$ walking (Dellinger, 2005), whereas the majority of children walks or bikes to school in Scandinavian countries (Cooper et al., 2006; Roberts et al., 1997). Data from Australia, the US and the United Kingdom suggest active commuting to school to be on the decrease (Department for Transport, 2006; Salmon et al., 2005; Ham et al., 2005).

In Switzerland, there is growing concern about the increase in childhood obesity (Zimmermann et al., 2004) but little data 
exist on children's physical activity levels, their mode of transportation to school and factors influencing commuting behavior. Results from Swiss transportation research indicates that physical activity and active mode of transportation in adults as well as children's active commuting to school are less prevalent in the French and Italian-speaking regions of Switzerland compared to the German-speaking part, suggesting a role of cultural factors (Stamm and Lamprecht, 2005; MartinDiener and Sauter, 2006).

As yet, current transportation research in Switzerland does not incorporate personal, familial or environmental correlates of children's commuting to school although a growing body of literature suggests that these factors strongly influence children's commuting behavior (Dellinger, 2005; Ewing et al., 2004; Timperio et al., 2006; Merom et al., 2005; Kerr et al., 2006; DiGuiseppi et al., 1998). However, in order to guide target-specific public health interventions, examination of such correlates is warranted. The Swiss surveillance program on childhood allergy and respiratory symptoms with respect to air pollution, SCARPOL (Braun-Fahrlander et al., 1997), has therefore been expanded to include questions on children's physical activity and journeys to school and linked to environmental data using a geographic information system. To address differences in commuting behavior across levels of urbanization and across language regions, the present study included urban and rural sites from the German and French-speaking part of the country, as well as a bilingual study site.

The primary purpose of the analyses was to assess whether the prevalence of active commuting to school varies across communities and to determine personal, familial and environmental factors related to active commuting to school. As children in Switzerland usually return home for lunch and therefore travel up to four times a day to or from school, isolated but regular car trips might not be considered when reporting main mode of transport. Therefore, this more subtle form of non-active traveling to school and its correlates were also evaluated.

\section{Methods}

\section{Study population}

For the present cross-sectional study, three out of ten original SCARPOL centers (Braun-Fahrlander et al., 1997) were selected: Bern, a German-speaking city with about 130000 inhabitants, Payerne a French-speaking rural town with about 8000 inhabitants and Biel/Bienne a town with about 50000 inhabitants speaking German or French. The study was conducted during the school year 2004/2005 and organized within the framework of the School Health Services. The children visit the Services routinely at the ages of 6-7 years (kindergarten or 1st class), 9-10 years (4th class) and 13-14 years (8th class). In Bern and Biel, a representative sample of children of all three age groups was invited to participate in the surveillance study. In Payerne, all children of the respective age group were asked to participate. A letter explaining the purpose of the study was distributed in school and parents were asked to fill in a detailed questionnaire at home.

A completed written parental questionnaire was available for a total of $1345(65 \%)$ invited children. One thousand sixty (79\%) of the children provided a home and a school address that could successfully be linked to environmental data using a geographic information system (GIS) (Geographic information system (GIS) Vector25 and version, 2004). Furthermore, 29 children spending four or more days a week away from the current home address were excluded. The present analyses are restricted to this subset of 1031 children. The study protocol was approved by the ethics committee of the University of Bern.

\section{Assessment of main mode of transport and regular car trips to school}

Two approaches have been used to assess factors, which could determine the mode of traveling to school. First, parents reported how their child usually travels to and from school, during winter and summer. Response categories included walking, traveling by bicycle/kick scooter/inline skates, traveling by car, using bus/tram/train or 'others'. Active commuting was defined as usually walking or cycling (including kick scooter and inline skates) to and from school both in winter and summer. This restrictive definition was chosen since active commuting is very common in Switzerland and factors affecting any form of non-active mode of transport - even if it is only partial or seasonal - are of interest. Second, parents were asked how often they were driving their child to school. Regular car trips were defined as such if parents drove their child to school at least once a week.

\section{Personal and family factors}

The questionnaire further included questions about the child's sex and nationality, maternal education (low: less than two years of professional training, medium: 2 to 4 years of professional training, high: college or university education), family structure (single versus dual parent family), regular day care attendance after school and the number of cars in the household. In addition, parents indicated their child's height and weight. High agreement was found between parental answers and height and weight measurements taken by the School Health Service of Bern (correlation coefficient $r=0.98$ for weight and $r=0.99$ for height). International age- and sex-specific cut-points were applied to body mass index to define overweight (Cole et al., 2000). Parents were further asked whether they perceived the way to school as safe, slightly unsafe or very unsafe, whether the child was in general allowed to go out after dark, whether the child was allowed to travel by bus by himself and whether they accompanied the child to school.

\section{Environmental data}

Environmental data were linked to the child's home and school addresses using a geographic information system (GIS) software package (Geographic information system (GIS) Vector25 and version, 2004; TwixRoute Tele Atlas, 2001). Distance to school was defined as the straight-line distance between home and school in meters. It was assessed whether this crossed a motorway, a main street or a side street. Since safety perception can also be influenced if children have to walk or cycle along busy roads, the total length (in meters) of each type of street segment in a buffer of $200 \mathrm{~m}$ around the straight-line distance was calculated. The altitude difference between home and school and the population density defined as the number of inhabitants in a square of 9 ha around the home address of each child (based on census data) were determined.

\section{Statistical analysis}

For statistical analysis, the reciprocal term of active mode of transport, nonactive, was used so results could be easily comparable to these of regular car trips. The one-to-one association of personal, familial and environmental characteristics with non-active mode of transport to school and with regular car trips was evaluated using logistic regression analyses. Factors significantly associated with one of the outcome variables were included in the multivariate models. After graphical inspection of the data, it was observed that the relation of distance between home and school and non-active mode of transport was not linear; therefore, a quadratic term was tested.

In addition, there was evidence of an interaction between community and distance to school for the association with non-active mode of transport to school. To illustrate this, the prevalence of non-active mode of transport to 
school, adjusted for covariates included in the multivariate model was plotted versus distance to school for each community using local non-parametric smoothing with a span of 0.7 .

All analyses were done with STATA version 8.0 (STATA Statistical Software, 2005), and local non-parametric smoothing was performed with SPLUS (S-PLUS, 2002).

\section{Results}

The study population consisted of 528 girls and 503 boys. Of the children, 34.6\% were living in Bern, $25 \%$ in Biel/Bienne (German-speaking), 28\% in Biel/Bienne (French-speaking) and $12.3 \%$ in Payerne. Table 1 gives the sociodemographic characteristics of the study population by age group and community.

Table 2 presents the distribution of personal, familial and environmental variables according to age group and community. With increasing age of children, the journey to school became longer and involved the crossing of more major roads but children were less often accompanied to school. Frenchspeaking children in Biel/Bienne and those living in Payerne had longer journeys to school and the straight-line distance between home and school crossed more often a main street.

Among all families, $77.8 \%$ indicated that their child usually travels to school using only active modes of transportation. Table 3 shows the main mode of transport by sex, age and community in detail. Children engaged in active transport less frequently in Payerne (51.3\%) compared with the other study areas (Bern 90.7\%, Biel/German 76:7\% and Biel/French 72.9\%, $p<0.001$ ), but no significant difference was observed between the two language groups within Biel/Bienne $(p=0.31)$. Active commuting was significantly more common in $9 / 10$ years olds $(88.2 \%)$ than in $6 / 7$ years olds $(75.6 \%)$ and $13 / 14$ years olds $(68.9 \%)(p<0.001)$. Although only very few children were driven to school by car as the usual mode of transportation, 120 (11.8\%) traveled to school by car at least once a week (Table 2).

Table 4 shows the results of the logistic regression evaluating the factors associated with non-active commuting as the usual mode of transportation (column 1) and those with regular car trips (column 2). Sex, maternal education, nationality, family structure and parental restrictions were not significantly associated with outcome variables and thus excluded from the final model.

Beside the child's age and the number of cars in the household, non-active commuting to school was mainly associated with distance of the way to school and crossings of main streets. As there was indication of an interaction between distance to school and community, community-specific effects for non-active commuting are also shown in Table 4. The community-specific association between non-active commuting and distance is illustrated in Fig. 1. At a distance of $500 \mathrm{~m}$, the adjusted prevalence of non-active commuting was lowest in Bern (3.2\%) followed by Biel/Bienne (13.1\% (Biel French) and $14.2 \%$ (Biel German)) and highest in Payerne (27.3\%).

Factors associated with regular car trips were quite different. Distance between home and school and crossings of major roads were not significantly associated with regular car trips. Yet, parents of French-speaking children, those who were concerned about the safety on the way to school, those with two or more cars and those whose children were at day care were more likely to regularly drive their children to school. The difference between language groups for regular car trips was also significant within $\mathrm{Biel} / \mathrm{Bienne}(\mathrm{OR}=2.7, p=0.005$ for $\mathrm{Biel} /$ Bienne French speaking, taking Biel/Bienne German speaking as reference).

When asked about the reason for driving their children to school, parents listed distance $(13.3 \%)$, having the same way to go $(20.8 \%)$, bad weather $(20.8 \%)$ and/or the child being late $(12.5 \%)$ as the main motives.

In general, most of the parents perceived their children's way to school as being safe (63.5\%). Those who considered it to be unsafe were mostly afraid of dangers from traffic $(84.9 \%)$, and/ or of violence or harassment by other children $(14.0 \%)$ or by adults $(12.1 \%)$ and were significantly more likely to accompany their children to school $(p<0.001)$. Yet, only about half of the

Table 1

Characteristics of study population by age group and community (children in Switzerland, school year 2004/2005)

\begin{tabular}{|c|c|c|c|c|c|c|c|c|c|}
\hline \multirow[t]{2}{*}{ Characteristic } & \multicolumn{4}{|c|}{ Age group, $n(\%)$} & \multicolumn{5}{|c|}{ Community, $n(\%)$} \\
\hline & $\begin{array}{l}6 / 7 \text { years, } \\
n=24 \\
(23.6 \%)\end{array}$ & $\begin{array}{l}9 / 10 \text { years, } \\
n=393 \\
(38.1 \%)\end{array}$ & $\begin{array}{l}13 / 14 \text { years, } \\
n=395 \\
(38.3 \%)\end{array}$ & $\begin{array}{l}\chi^{2} \\
p \text {-value }\end{array}$ & $\begin{array}{l}\text { Bern } \\
\text { (German), } \\
n=357 \\
(34.6 \%)\end{array}$ & $\begin{array}{l}\text { Biel } \\
\text { (German), } \\
n=258 \\
(25.0 \%)\end{array}$ & $\begin{array}{l}\text { Biel } \\
\text { (French), } \\
n=289 \\
(28.0 \%)\end{array}$ & $\begin{array}{l}\text { Payerne } \\
\text { (French), } \\
n=127 \\
(12.3 \%)\end{array}$ & $\begin{array}{l}\chi^{2}, \\
p \text {-value }\end{array}$ \\
\hline Sex: female & $112(46.1)$ & $201(51.2)$ & $215(54.4)$ & 0.12 & $175(49.3)$ & $132(51.2)$ & $154(53.3)$ & $67(52.8)$ & 0.72 \\
\hline \multicolumn{10}{|l|}{ Maternal education } \\
\hline Low & $29(12.1)$ & $69(18.0)$ & 78 (20.2) & 0.11 & $35(9.9)$ & $41(16.3)$ & $75(26.8)$ & $25(20.3)$ & $<0.001$ \\
\hline Medium & $119(49.8)$ & $181(47.1)$ & $184(47.8)$ & & $156(44.2)$ & $132(52.4)$ & $125(44.6)$ & $71(57.7)$ & \\
\hline High & $91(38.1)$ & $134(34.9)$ & $123(32.0)$ & & $162(45.9)$ & 79 (31.3) & $80(28.6)$ & $27(22.0)$ & \\
\hline \multicolumn{10}{|l|}{ Nationality } \\
\hline Non-Swiss & $42(17.3)$ & $91(23.3)$ & $90(23.0)$ & 0.16 & $56(15.7)$ & $60(23.3)$ & $86(30.1)$ & $21(16.7)$ & $<0.001$ \\
\hline $\begin{array}{l}\text { Child lives with } \\
\text { both parents: yes }\end{array}$ & $204(84.7)$ & $306(79.1)$ & $268(68.9)$ & $<0.001$ & $279(78.8)$ & $190(74.5)$ & $204(72.6)$ & $105(82.7)$ & 0.08 \\
\hline $\begin{array}{l}\text { Regular after-school } \\
\text { daycare attendance: yes }\end{array}$ & $64(26.8)$ & $68(17.8)$ & $48(12.7)$ & $<0.001$ & $83(23.9)$ & $38(15.2)$ & $43(15.5)$ & $16(12.7)$ & $<0.01$ \\
\hline Overweight: ${ }^{\mathrm{a}}$ yes & $20(9.9)$ & $38(11.1)$ & $42(12.0)$ & 0.73 & $39(12.3)$ & $21(9.6)$ & $31(12.0)$ & $9(9.1)$ & 0.65 \\
\hline
\end{tabular}

a Age- and gender-specific definition of overweight according to Cole et al. (2000). 
Table 2

Distribution of personal, familial and environmental variables by age group and community (children in Switzerland, school year 2004/2005)

\begin{tabular}{|c|c|c|c|c|c|c|c|c|c|}
\hline \multirow[t]{2}{*}{ Variable } & \multicolumn{4}{|l|}{ Age group, $n(\%)$} & \multicolumn{5}{|l|}{ Community, $n(\%)$} \\
\hline & $\begin{array}{l}6 / 7 \text { years, } \\
n=243\end{array}$ & $\begin{array}{l}9 / 10 \text { years, } \\
n=393\end{array}$ & $\begin{array}{l}13 / 14 \text { years, } \\
n=395\end{array}$ & $p$-value ${ }^{\mathrm{a}}$ & $\begin{array}{l}\text { Bern } \\
\text { (German), } \\
n=357\end{array}$ & $\begin{array}{l}\text { Biel } \\
\text { (German), } \\
n=258\end{array}$ & $\begin{array}{l}\text { Biel } \\
\text { (French), } \\
n=289\end{array}$ & $\begin{array}{l}\text { Payerne } \\
\text { (French), } \\
n=127\end{array}$ & $p$-value ${ }^{\mathrm{a}}$ \\
\hline \multicolumn{10}{|l|}{ Parental safety assessment of the way to school } \\
\hline Safe & $123(51.0)$ & $245(63.1)$ & 279 (71.5) & $<0.001$ & $215(60.4)$ & $163(64.7)$ & $188(66.0)$ & $81(64.3)$ & 0.16 \\
\hline Slightly unsafe & 99 (41.1) & $129(33.3)$ & $106(27.2)$ & & $127(35.7)$ & 79 (31.4) & $83(29.1)$ & $45(35.7)$ & \\
\hline Very unsafe & $19(7.9)$ & $14(3.6)$ & $5(1.3)$ & & $14(3.9)$ & $10(4.0)$ & $14(4.9)$ & $0(0.0)$ & \\
\hline \multicolumn{10}{|l|}{ Children accompanied to school ${ }^{\text {b }}$} \\
\hline Daily/almost daily & $129(53.7)$ & $29(7.5)$ & - & $<0.001$ & $58(25.3)$ & $36(20.9)$ & $35(23.8)$ & $29(35.8)$ & 0.07 \\
\hline Once per week & $23(9.6)$ & $14(3.6)$ & - & & $13(5.7)$ & $7(4.1)$ & $9(6.1)$ & $8(9.9)$ & \\
\hline Almost never/never & $88(36.7)$ & $346(88.9)$ & - & & $158(69.0)$ & $129(75.0)$ & $103(70.1)$ & $44(54.3)$ & \\
\hline Allowed to go by bus by himself: ${ }^{\text {b yes }}$ & $4(1.7)$ & $237(61.1)$ & - & $<0.001$ & 85 (37.6) & $85(49.1)$ & $64(43.5)$ & $7(8.9)$ & $<0.001$ \\
\hline $\begin{array}{l}\text { Allowed to go out alone after dark } \\
\text { in general: }{ }^{\text {b yes }}\end{array}$ & $6(2.5)$ & $43(11.1)$ & - & $<0.001$ & $17(7.5)$ & $19(11.1)$ & $7(4.8)$ & $6(7.3)$ & 0.22 \\
\hline \multicolumn{10}{|l|}{ Number of cars in the household } \\
\hline None & $51(21.1)$ & 79 (20.2) & $70(17.9)$ & 0.08 & $99(28.0)$ & $54(21.2)$ & $43(14.9)$ & $4(3.2)$ & $<0.001$ \\
\hline One & $152(62.8)$ & $254(65.0)$ & $234(59.9)$ & & $222(62.7)$ & $164(64.3)$ & $186(64.6)$ & $68(53.5)$ & \\
\hline Two or more & $39(16.1)$ & $58(14.8)$ & $87(22.2)$ & & $33(9.3)$ & $37(14.5)$ & $59(20.5)$ & $55(43.3)$ & \\
\hline \multicolumn{10}{|l|}{ Regular car trips to school } \\
\hline At least once a week & $48(20.1)$ & $40(10.3)$ & $32(8.2)$ & $<0.001$ & $20(5.7)$ & $17(6.7)$ & $42(14.6)$ & $41(33.6)$ & $<0.001$ \\
\hline Motorway crossing: yes & $1(0.4)$ & $10(2.5)$ & $29(7.4)$ & $<0.001$ & $19(5.3)$ & $1(0.4)$ & $16(5.5)$ & $4(3.2)$ & $<0.01$ \\
\hline Main street crossing: yes & $90(37.0)$ & 147 (37.4) & $278(71.3)$ & $<0.001$ & $136(38.6)$ & $111(43.0)$ & $179(61.9)$ & $89(70.1)$ & $<0.001$ \\
\hline Side street crossing: yes & $215(88.5)$ & $369(93.9)$ & $386(97.7)$ & $<0.001$ & 345 (96.6) & $239(92.6)$ & $274(94.8)$ & $112(88.2)$ & $<0.01$ \\
\hline $\begin{array}{l}\text { Straight-line distance between home and school } \\
\text { in meters: median (range) }\end{array}$ & $317(7-4705)$ & $406(7-4919)$ & $775(65-11388)$ & & $393(10-4012)$ & $472(7-8092)$ & $538(8-10744)$ & 769 (51-11388) & $<0.001$ \\
\hline \multicolumn{10}{|c|}{ Length of street segments in a buffer area of $200 \mathrm{~m}$ around the way to school } \\
\hline Motorway, mean (range) ${ }^{\mathrm{c}}$ & $17.2(0-934)$ & $39.7(0-1353)$ & $89.7(0-1891)$ & $<0.001$ & $83.6(0-1891)$ & $16.1(0-1211)$ & $55.4(0-829)$ & $40.5(0-1354)$ & $<0.001$ \\
\hline Main street, median (range) & $488(0-2638)$ & $436(0-3909)$ & $1102(0-6548)$ & $<0.001$ & $447(0-4197)$ & $565(0-6548)$ & $782(0-5319)$ & $1208(0-4047)$ & $<0.001$ \\
\hline Side street, median (range) & $3154(0-10735)$ & $3696(792-12381)$ & $5412(1398-22290)$ & $<0.001$ & 4291 (1014-22290) & $3821(421-19936)$ & $4476(1267-17750)$ & $3031(0-11638)$ & $<0.001$ \\
\hline $\begin{array}{l}\text { Altitude difference between home and school in } \\
\text { meters, median (range) }\end{array}$ & $3.5(0-110)$ & $5.3(0-141)$ & $4.6(0-552)$ & $<0.001$ & $5.3(0-110)$ & $4.3(0-552)$ & $3.5(0-302)$ & $3.7(0-222)$ & 0.88 \\
\hline $\begin{array}{l}\text { Population density in a square of } 9 \text { ha around } \\
\text { home in number of inhabitants, median (range) }\end{array}$ & $599(7-1731)$ & $584(15-1942)$ & $589(18-1856)$ & 0.68 & $722(7-1942)$ & $554(15-1306)$ & $596(19-1233)$ & $155(10-852)$ & $<0.001$ \\
\hline
\end{tabular}

${ }^{a}$ Chi-square test of significance between groups for categorical and Kruskal-Wallis test for continuous variables.

${ }^{\mathrm{b}}$ Question asked only in the two younger age groups.

c Arithmetic mean given instead of median since less than $10 \%$ of the children have a segment of a motorway in their buffer area. 
Table 3

Main mode of transportation by sex, age and community (children in Switzerland, school year 2004/2005)

\begin{tabular}{|c|c|c|c|c|c|c|}
\hline & \multicolumn{3}{|c|}{ Any mode of active transportation } & \multicolumn{3}{|c|}{ Non-active mode of transportation } \\
\hline & Walking & $\begin{array}{l}\text { Bike/kick } \\
\text { scooter/inline } \\
\text { skates }\end{array}$ & $\begin{array}{l}\text { Combination of walking } \\
\text { and biking/kick } \\
\text { scooter/inline skates }\end{array}$ & Car & $\begin{array}{l}\text { Public } \\
\text { transportation }\end{array}$ & $\begin{array}{l}\text { Combination of car/public } \\
\text { transportation with any other } \\
\text { mode of transportation }\end{array}$ \\
\hline \multicolumn{7}{|l|}{ By sex } \\
\hline Male & $246(50.4 \%)$ & $41(8.4 \%)$ & $84(17.2 \%)$ & $4(0.8 \%)$ & $38(7.8 \%)$ & $75(15.4 \%)$ \\
\hline Female & $297(57.6 \%)$ & $29(5.6 \%)$ & $84(16.3 \%)$ & $7(1.4 \%)$ & $33(6.4 \%)$ & $66(12.8 \%)$ \\
\hline \multicolumn{7}{|l|}{ By age } \\
\hline 6/7 years & $166(69.8 \%)$ & $7(2.9 \%)$ & $7(2.9 \%)$ & $7(2.9 \%)$ & $13(5.5 \%)$ & $38(16.0 \%)$ \\
\hline $9 / 10$ years & $245(64.1 \%)$ & $25(6.5 \%)$ & $67(17.5 \%)$ & $2(0.5 \%)$ & $15(3.9 \%)$ & $28(7.3 \%)$ \\
\hline 13/14 years & $132(34.3 \%)$ & $38(9.9 \%)$ & $95(24.7 \%)$ & $2(0.5 \%)$ & $43(11.2 \%)$ & $75(19.5 \%)$ \\
\hline \multicolumn{7}{|l|}{ By community } \\
\hline Bern (German) & $220(62.3 \%)$ & $25(7.1 \%)$ & $78(22.1 \%)$ & $1(0.3 \%)$ & $4(1.1 \%)$ & $25(7.1 \%)$ \\
\hline Biel/Bienne (German) & $131(52.6 \%)$ & $13(5.2 \%)$ & $46(18.5 \%)$ & $1(0.4 \%)$ & $24(9.6 \%)$ & $34(13.7 \%)$ \\
\hline Biel/Bienne (French) & $153(53.9 \%)$ & $21(7.4 \%)$ & $34(12.0 \%)$ & $6(2.1 \%)$ & $22(7.8 \%)$ & $48(16.9 \%)$ \\
\hline Payerne (French) & $39(32.8 \%)$ & $11(9.2 \%)$ & $11(9.2 \%)$ & $3(2.5 \%)$ & $21(17.7 \%)$ & $34(28.6 \%)$ \\
\hline Total & $543(54.0 \%)$ & $70(7.0 \%)$ & $169(16.8 \%)$ & $11(1.1 \%)$ & $71(7.1 \%)$ & $141(14.0 \%)$ \\
\hline
\end{tabular}

kindergarten/1st grade children and about $7 \%$ of the 4 th grade children were accompanied to school.

\section{Discussion}

Compared to countries like the US (Dellinger, 2005) and Australia (Merom et al., 2005), the number of children walking or cycling to school in Switzerland is still high and comparable to that in Scandinavian countries (Cooper et al., 2006; Roberts et al., 1997). The vast majority of Swiss children attend schools that are easily accessible from home via active transport. Consequently, the median straight-line distance between home and school in this study was below 500m and considerably shorter than reported, for example, by other studies form the UK (DiGuiseppi et al., 1998) or Australia (Merom et al., 2005). The relatively high proportion of parents $(63 \%)$ perceiving their children's way to school to be safe is likely to further contribute to the high levels of active commuting. Safety concerns of parents were mostly related to dangers from traffic $(85 \%)$ and less often to violence and harassment $(23 \%)$. This is in contrast to reports, e.g. from the UK, where $90 \%$ of the parents of 6 - to 10 -year-old children were worried about abduction or molestation and 89\% because of traffic (DiGuiseppi et al., 1998). An earlier study conducted in the UK showed that over $40 \%$ of English parents restricted schoolchildren aged 7-11 years from coming home alone from school because of traffic danger, while around $20 \%$ of parents enforced this restriction due to fear of assault or molestation by an adult (Hillman et al., 1990).

In line with previous reports (Dellinger, 2005; Ewing et al., 2004; Timperio et al., 2006; Merom et al., 2005), distance to school and objectively measured busy road barriers were significantly associated with non-active commuting. The present study found the association between distance and nonactive commuting to significantly vary between the communities. At relatively short distances to school $(500 \mathrm{~m})$, children in urban areas with denser neighborhoods were more likely to walk or cycle to school than in the more rural area of Payerne. A recent study from Melbourne (Timperio et al., 2006) reported that children living in neighborhoods with many other children were more likely to walk or cycle to school suggesting that opportunities to travel to school in the company of other children supports active commuting. The possibility of socialization for children may increase parental perception of safety. In keeping with this argument, we found more children in Payerne to be accompanied to school by their parents than in the urban areas.

Despite the high proportion of children actively traveling to school, transport research from Switzerland indicates that between 1994 and 2000 the use of motorized transportation among primary school children in the French-speaking part of the country (Sauter, 2005) has increased. Thus, the $12 \%$ children regularly driven to school in the present study may represent the beginning of a development from active to passive commuting in Switzerland that has already occurred in other countries (Department for Transport, 2006; Salmon et al., 2005; Ham et al., 2005). For public health interventions aiming to prevent an increase in children using regular car trips, it is important to understand the underlying reasons for these parental habits. The results of the present study suggest that a variety of factors affect parental behavior namely the age of the child, safety concerns, the availability of two and more cars in the household as has been reported by others (Dellinger, 2005; Kerr et al., 2006; DiGuiseppi et al., 1998), maternal employment (indirectly estimated as the child attending day care) and a cultural factor associated with belonging to the French-speaking part of the population. The difference in built environment between Bern and Payerne may to some extent explain the frequency of regular car trips. However, the significantly higher prevalence of driven children to school in Biel/French to Biel/ German, which have the same level of urbanization, argues in favor of a cultural factor influencing parental behavior. It is known from previous surveys in Switzerland that subjects living in the German-speaking part of the country differ in many lifestyle ways from those living in the French or Italianspeaking part. They report less smoking, less alcohol consumption, healthier dietary habits, less exposure to environmental 
Table 4

Predictors for non-active commuting as main mode of transport and for regular car trips, adjusted associations (children in Switzerland, school year 2004/2005)

\begin{tabular}{|c|c|c|}
\hline \multirow[t]{2}{*}{ Variables } & \multirow{2}{*}{$\begin{array}{l}\text { Non-active commuting } \\
\text { as main mode of } \\
\text { transportation }^{\mathrm{a}} \\
\text { Adjusted OR }^{\mathrm{b}} \\
(95 \% \mathrm{CI})\end{array}$} & \multirow{2}{*}{$\begin{array}{l}\text { Regular car trips } \\
\text { Adjusted OR } \\
(95 \% \mathrm{CI})\end{array}$} \\
\hline & & \\
\hline \multicolumn{3}{|l|}{ Age group } \\
\hline 6/7 years olds (ref.) & 1.0 & 1.0 \\
\hline $9 / 10$ years olds & $0.2(0.1,0.4)^{* * *}$ & $0.5(0.3,0.9)^{* *}$ \\
\hline $13 / 14$ years olds & $0.2(0.1,0.4)^{* * *}$ & $0.2(0.09,0.4)^{* * *}$ \\
\hline \multicolumn{3}{|l|}{ Community } \\
\hline Bern (ref.) & 1.0 & 1.0 \\
\hline Biel (German) & $0.5(0.1,1.7)$ & $1.2(0.6,2.6)$ \\
\hline Biel (French) & $0.9(0.3,2.7)$ & $3.2(1.6,6.1)^{* * *}$ \\
\hline Payerne & $1.6(0.5,5.4)$ & $9.1(3.4,24.2)^{* * *}$ \\
\hline \multicolumn{3}{|l|}{ Number of Cars } \\
\hline None (ref.) & 1.0 & 1.0 \\
\hline One & $1.0(0.5,1.7)$ & $2.8(1.2,6.6)^{*}$ \\
\hline Two or more & $3.1(1.5,6.4)^{* *}$ & $6.9(2.7,17.4) * * *$ \\
\hline Regular day care attendance: yes & $1.1(0.6,2.0)$ & $2.0(1.1,3.4)^{*}$ \\
\hline \multicolumn{3}{|c|}{ Parental assessment of the way to school } \\
\hline Safe (ref.) & 1.0 & 1.0 \\
\hline Slightly unsafe & $1.0(0.6,1.5)$ & $3.1(2.0,5.1)^{* * *}$ \\
\hline Very unsafe & $1.5(0.5,3.9)$ & $4.8(1.8,12.9)^{* *}$ \\
\hline $\begin{array}{l}\text { Distance between home } \\
\text { and school }\end{array}$ & - & $1.0(0.9,1.1)$ \\
\hline \multicolumn{3}{|c|}{ Community-specific effect of the distance between home and school ${ }^{\mathrm{d}}$} \\
\hline Bern & $3.5(2.4,6.3)^{* * *}$ & - \\
\hline Biel (German) & $5.1(2.1,12.8)^{* * *}$ & - \\
\hline Biel (French) & $2.0(1.0,4.0)^{*}$ & - \\
\hline Payerne & $0.8(0.4,1.7)$ & - \\
\hline Motorway crossing: yes & $1.7(0.2,11.4)$ & $2.4(0.4,13.2)$ \\
\hline Main street crossing: yes & $2.2(1.3,4.0)^{* *}$ & $1.3(0.7,2.3)$ \\
\hline Side street crossing: yes & $0.9(0.3,2.7)$ & $2.9(0.9,9.8)$ \\
\hline \multicolumn{3}{|c|}{$\begin{array}{l}\text { Length of street segments in a buffer area of } 200 \mathrm{~m} \text { around the way to } \\
\text { school in } \mathrm{m} \text { : }\end{array}$} \\
\hline Motorway $^{\mathrm{e}}$ & $1.0(0.8,1.2)$ & $1.0(0.8,1.2)$ \\
\hline Main street ${ }^{\mathrm{f}}$ & $1.3(1.0,1.9)$ & $1.0(0.7,1.4)$ \\
\hline Side street ${ }^{\mathrm{f}}$ & $0.6(0.4,1.1)$ & $1.3(0.9,1.9)$ \\
\hline $\begin{array}{l}\text { Altitude difference between home } \\
\text { and } \text { school }^{\mathrm{g}}\end{array}$ & $1.0(0.9,1.1)$ & $1.0(1.0,1.1)$ \\
\hline $\begin{array}{l}\text { Population density in a square of } \\
9 \text { ha around the domicile }\end{array}$ & $0.9(0.6,1.2)$ & $1.0(0.7,1.5)$ \\
\hline
\end{tabular}

$* p \leq 0.05 ; * * p \leq 0.005 ; * * * p \leq 0.001$.

$\mathrm{CI}$, confidence interval; OR, odds ratio; $\mathrm{KG}$, kindergarten.

a To make the OR for "main mode of transport" and "regular car trips" comparable, non-active commuting has been used. Non-active commuting includes all children who did not exclusively walk or use a bike/kick scooter/ inline skates as main mode of transportation to school.

b Mutually adjusted odds ratio.

c Calculated for the increase of the interquartile range of the distance: 268-824 m.

d Calculated from the terms of the interaction between community and distance to school (for the increase of the interquartile range of 268-824 m).

e Calculated for an increase of $100 \mathrm{~m}$ (less than $10 \%$ of the children have a segment of a motorway in their buffer area).

${ }^{f}$ Calculated for the increase of the interquartile range of the length of the segments: $347-1146 \mathrm{~m}$ for main street and 2821-5891 m for side streets.

$\mathrm{g}$ Calculated for the increase of the interquartile range of the altitude difference: $1.4-12.4 \mathrm{~m}$.

${ }^{\mathrm{h}}$ Calculated for the increase of the interquartile range of the population density: 393-827 inhabitants.

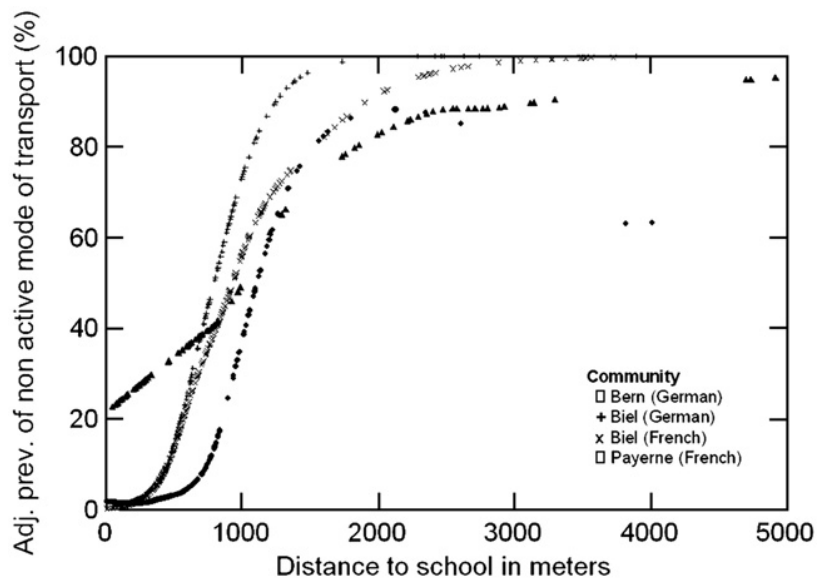

Fig. 1. Smoothed plot of the adjusted prevalence of non-active mode of transport to school and distance from home to school for each community (span of 0.7 ). (Children in Switzerland, school year 2004/2005).

tobacco smoke and higher levels of physical activity (Calmonte et al., 2005; Lamprecht and Stamm, 2005). Yet, research into the underlying reasons for these lifestyle differences is only at its beginning and no definite explanations have emerged so far.

\section{Study strength and limitations}

Strengths of this study are the inclusion of GIS-based environmental data as well as sociocultural data to examine children's active transport within a socioeconomically homogeneous country. Nevertheless, there are also several limitations that have to be considered: the straight-line distance between home and school used as our measure of distance is only an approximation because in reality, children may travel longer distances. Yet, it is likely that the effective distance and the straight-line distance are closely correlated. In addition, nonSwiss parents are underrepresented compared to Swiss families limiting the generalization of the findings to the whole population living in Switzerland (proportion of non-Swiss people in Bern: 22.8\%; in Biel: 26.1\%; and in Payerne: $28.3 \%$ ) (Bundesamt für Statistik, 2002). Further, it would have been desirable to include communities with different levels of the built environment of both language areas. Nevertheless, the study design allowed to assess cultural differences within the bilingual community of Biel/Bienne, a town with uniform environmental conditions and thus to separate to some degree the effect of the built environment from cultural influences. Another limitation is that personal and family factors had to rely on parental reporting. An influence thorough social desirability cannot be totally excluded. Finally, the present study is crosssectional in design so causality may not be inferred.

\section{Conclusions}

Objective predictors as the distance and major road crossings are main deciding factors for active commuting to school as main mode of transport. To maintain high levels of active mode of transportation in Switzerland and to prevent declining levels 
observed in other countries, distances between home and school have to be kept short and children's safety as pedestrians or cyclists has to be improved. In contrast, personal and lifestyle factors are important factors associated with frequency of car use. Campaigns promoting non-motorized travel to school have to make allowance for differing cultural attitudes of the respective populations.

\section{Acknowledgments}

The authors are grateful to their many colleagues in the School Health Services of Bern, Biel and Payerne who organized the survey. We should also like to thank the children, parents and teachers for their enthusiastic co-operation, which made this investigation possible. The study was supported by a grant of the Federal Commission of Sport (ESK).

\section{References}

Andersen, L.B., Harro, M., Sardinha, L.B., et al., 2006. Physical activity and clustered cardiovascular risk in children: a cross-sectional study (The European Youth Heart Study). Lancet 368, 299-304.

Biddle, S.J., Gorely, T., Stensel, D.J., 2004. Health-enhancing physical activity and sedentary behaviour in children and adolescents. J. Sports Sci. 22, 679-701.

Bundesamt für Statistik, 2002. Satistik Schweiz. Available at www.bfs.admin.ch. Braun-Fahrlander, C., Vuille, J.C., Sennhauser, F.H, Neu, U., Kunzle, T., Grize, L., et al., 1997. Respiratory health and long-term exposure to air pollutants in Swiss schoolchildren. SCARPOL Team. Swiss Study on Childhood Allergy and Respiratory Symptoms with Respect to Air Pollution, Climate and Pollen. Am. J. Respir. Crit. Care Med. 155, 1042-1049.

Calmonte, R., Galatai-Petrecca, M., Lieberherr, R., Neuhaus, M., Kahlmeier, S., 2005. Gesundheit und Gesundheitsverhalten in der Schweiz 1992-2002. Schweizerische Gesundheitsbefragung. Neuchâtel BFS-Statistik der Schweiz: 93

Cole, T.J., Bellizzi, M.C., Flegal, K.M., Dietz, W.H., 2000. Establishing a standard definition for child overweight and obesity worldwide: international survey. BMJ 320, 1240-1243.

Cooper, A.R., Wedderkopp, N., Wang, H., Andersen, L.B., Froberg, K., Page, A.S., 2006. Active travel to school and cardiovascular fitness in Danish children and adolescents. Med. Sci. Sports Exerc. 38, 1724-1731.

Dellinger, A.M., 2005. Barriers to children walking to or from school-United States, 2004. MMWR Morb. Mortal. Wkly. Rep. 54, 949-952.

Department for Transport, 2006. National Travel Survey: 2005. Transport Statistics Bulletin. Department of Transport, London.

DiGuiseppi, C., Roberts, I., Li, L., Allen, D., 1998. Determinants of car travel on daily journeys to school: cross sectional survey of primary school children. BMJ 316, 1426-1428.

Ewing, R., Schroeer, W., Greene, W., 2004. School location and student travel. Transp. Res. Rec. 1895, 55-63.
Geographic information system (GIS) Vector25, version 2004. Available at: http://www.swisstopo.ch/de/products/digital/landscape/vec25/.

Ham, S.A., Macera, C.A., Lindley, C., 2005. Trends in walking for transportation in the United States, 1995 and 2001. Prev. Chronic. Dis. 2, A14.

Hillman, M., Adams, J., Whitelegg, J., 1990. One false move...: a study of children's independent mobility. PSI Publishing London

Kerr, J., Rosenberg, D., Sallis, J.F, Saelens, B.E., Frank, L.D., Conway, T.L., 2006. Active commuting to school: associations with environment and parental concerns. Med. Sci. Sports Exerc. 38, 787-794.

Lamprecht, M., Stamm, H.P., 2005. Bewegung. Sport. Gesundheit in der Schweiz. Forschungsbericht des Observatoriums, Sport und Bewegung Schweiz'. Bundesamt für Sport (BASPO)/L\&S Sozialforschung und Beratung AG, Magglingen/Zürich.

Mackett, R.L., Lucas, L., Paskins, J., Turbin, J., 2005. The therapeutic value of children's everyday travel. Transp. Res., Part A 39, 205-219.

Martin-Diener, E., Sauter, D., 2006. Walking and cycling behaviour of children and young adults in Switzerland: results from the Travel Survey 2000. In: Hoppeler, H., Reilly, T., Tsolakidis, E., Gfeller, L., Klossner, S. (Eds.), Book of Abstracts of the 11th annual congress of the European College of Sport Science Ed. European College of Sport Science, Lausanne.

Merom, D., Tudor-Locke, C., Bauman, A., Rissel, C., 2005. Active commuting to school among NSW primary school children: implications for public healthHealth Place. Oct 29

Roberts, I., Carlin, J., Bennett, C., Bergstrom, E., Guyer, B., Nolan, T., et al., 1997. An international study of the exposure of children to traffic. Inj. Prev. 3, 89-93.

Salmon, J., Timperio, A., Cleland, V., Venn, A., 2005. Trends in children's physical activity and weight status in high and low socio-economic status areas of Melbourne, Victoria, 1985-2001. Aust. N. Z. J. Public Health 29, $337-342$.

Sauter, D., 2005. Mobilität von Kindern und Jugendlichen. Vergleichende Auswertungen der Mikrozensen zum Verkehrsverhalten 1994 und 2000. Magglingen und Bern, Bundesamt für Sport BASPO und Bundesamt für Strassen ASTRA.

Sirard, J.R., Riner, W.F., McIver, K.L., Pate, R.R., 2005. Physical activity and active commuting to elementary school. Med. Sci. Sports Exerc. 37, 2062-2069.

S-PLUS, 2002. Release 6.1 (Insightful Corp., Seattle/Washington)

Stamm, H., Lamprecht, M., 2005. Structural and cultural factors influencing physical activity in Switzerland. J. Public Health 13, 203-211.

STATA Statistical Software, 2005. Release 8 (Stata Corp., College Station/ Texas).

Timperio, A., Ball, K., Salmon, J., Roberts, R., Giles-Corti, B., Simmons, D., et al., 2006. Personal, family, social, and environmental correlates of active commuting to school. Am. J. Prev. Med. 30, 45-51.

Tudor-Locke, C., Neff, L.J., Ainsworth, B.E., Addy, C.L., Popkin, B.M., 2002. Omission of active commuting to school and the prevalence of children's health-related physical activity levels: the Russian Longitudinal Monitoring Study. Child Care Health Dev. 28, 507-512.

TwixRoute Tele Atlas, 2001. Version 25. Available at: http://www.twixtel.ch/ twixroute.asp.

Zimmermann, M.B., Gubeli, C., Puntener, C., Molinari, L., 2004. Overweight and obesity in 6-12 year old children in Switzerland. Swiss Med. Wkly. 134, 523-528. 